Article

\title{
Bioenergy in an Agroforestry Economy under Crisis: Complement and Conflict. La Araucanía, Chile, 1990-2016
}

\author{
Fabián Almonacid \\ Instituto de Historia y Ciencias Sociales, Universidad Austral de Chile, Valdivia 5110566, Chile; \\ falmonac@uach.cl; Tel.: +56-63-2221-768
}

Received: 29 October 2018; Accepted: 26 November 2018; Published: 28 November 2018

\begin{abstract}
Following the collapse of Chile's energy mix in 2000, standalone bioenergy generation plants were installed in Lautaro, Region of La Araucanía, in 2011, purchasing biomass from the forest and agricultural industries. This article resorts to a historical method, using government sources-particularly projects submitted to the State's environmental approval process; news reports; corporate information and documents; interviews with employees, entrepreneurs and experts; field visits; and general literature. This article focuses on the success case of a bioenergy generation company and its relationship with wood and agricultural biomass suppliers in a region where traditional farming and forest plantations are under crisis. Currently, two additional bioenergy projects are underway in the Region. Beyond the economic crisis that is currently affecting this Region, local communities have increasingly been opposing the new plants and the price of electric energy has dropped, leading to an uncertain future for bioenergy in the south of Chile.
\end{abstract}

Keywords: bioenergy; biomass; crisis; sustainability; conflict

\section{Introduction}

To reduce energy dependence on hydrocarbons and the resulting pollution, there was world consensus on the need to increase renewable energies in the short term. In 2009, Europe made a pledge to reach, by $2020,20 \%$ of renewables in the total energy produced, and $10 \%$ in transport. Similarly, in the United States, almost 30\% of the use covered by oil is expected to come from biomass energy by 2030 [1].

Among the new sources of energy, bioenergy emerged as an excellent response to the energy issue, given the abundance of biomass in the form of farm and wood waste, asl well as crops suitable for that purpose.

The great bioenergy potential has become apparent [2]. Forest plantations have increased considerably around the world—at least by 52\% between 1990 and 2010-reaching 264 million ha. Among the fastest growing areas are New Zealand, Chile and Australia. Likewise, there are large biomass volumes coming from farming and agribusiness waste. Only in Europa, fruit and vegetable production generates 192 million tons annually [3]. Therefore, estimated future availability is expected to reach a yearly 71 million tons of biomass for bioenergy in California by 2050 [4].

Figures look promising around the world. At present, roughly $40 \%$ of biomass potential is used [5]. China has become a world leader in the promotion of biomass electricity generation. It has 460 million tons of carbon equivalent biomass per year, but uses less than 5\% [6]. At the same time, Turkey produces 30 million tons of agroforestry and agro-industrial waste every year. Malaysia's figure is even larger: 168 million tons of agroforestry biomass, and additionally projects to use 20 million tons of palm oil for biomass by 2020 [7]. Pakistan, a large agricultural producer, has abundant biomass 
available: only sugar cane waste amounts to 5.7 million metric tons per year, while cotton reaches 1.4 million metric tons [8]. On the other hand, Indonesia has an estimated of 7.26 million tons of forest waste available for bioenergy generation, both from plantations and industries [9].

In Chile, the increase in the demand for energy, in contrast with a limited supply, is one of the most complex issues of recent decades. The country's energy mix mainly includes thermal power (coal, oil and gas) and hydropower. In addition, Chile lacks hydrocarbons, leading to high levels of dependence and instability.

Energy generation was already under crisis by the end of the nineties, asl clearly evidenced by the depletion of domestic hydrocarbon production, the closing of coal mines and the strong resistance to the setting up of large-scale hydroelectric power stations (Ralco case in Alto Bío-Bío, 1994-2003) [10]. All of this raised the price of energy in Chile. In this context, the arrival of gas from Argentina (1997-2004) provided temporary relief to the domestic economy [11-13]. Energy prices dropped considerably, with figures from US\$25 to US\$30 per megawatt-hour (MWh). As of 2004, Argentinean gas supply declined and electricity prices doubled; in 2005, prices reached US $\$ 50$ per MWh and topped US $\$ 100$ per MWh in 2008. In the case of residential energy, the price of one MWh increased from U\$42 to US\$350, between 2004 and 2008. This finally drove Argentinean gas out of Chile, liquid natural gas began to be purchased abroad at prices six or seven times higher and thermoelectric power plants shifted to diesel and coal—with higher prices for both inputs—sparking a widespread debate around the environmental costs of such level of reliance.

Against this backdrop, a 2008 act promoted Non-Conventional Renewable Energies (NCREs) basically defining them as biomass, geothermal, solar, wind, and hydro-power energy sources below 20 MW. Furthermore, the act sets forth the obligation for plants generating more than $20 \mathrm{MW}$ to introduce-in the upcoming years-up to $10 \%$ of own or third-party NCREs to their output. In the following years, this originated the growth of NCREs in Chile, or a true energy revolution, asl some stakeholders call it [14]. Certainly, the development of NCREs has had a direct impact on the areas where they are located. While some cases have motivated positive response and participation by local populations, others have raised mounting concerns.

The south of Chile-the focus of this article and an area abundant in water resources, mountain landscapes and farming economies-has been a preferential space for the implementation of hydro-power, wind and thermal projects. This paper particularly explores bioenergy, i.e., the production of energy from wood and agricultural biomass developed at a relatively significant scale within La Araucanía in the past few years.

While the narrative of advocate companies points to clean production using the residues of industries in the area-reason for which the setting up of biomass plants is only expected to have economic, social and environmental benefits-there is a need to consider (as is done in this article) the levels of productive complements between bioenergy and forest and agricultural activities, asl well as any potential production and social conflicts this may cause. Specifically, bioenergy generation is said to be part of an agroforestry economy with a productive framework that is at the same time complex and under crisis: with the existence of a forest industry under expansion that has concentrated huge tracts of land, displaced indigenous Mapuche and farming communities, and created few benefits for local communities; traditional agriculture (crops and livestock) troubled by low commodity prices and competition from foreign imports; and Mapuche and general rural communities living under the country's worst poverty conditions.

Bioenergy plants cannot be understood aside from their relationships with the forest industry, including the direct ownership of plants themselves. It is not surprising, hence, for local communities to consider them as an additional branch of large forest companies. Thus, bioenergy comes to further aggravate what many consider as an already exhausted productive scheme, even if displayed as clean energy. On the other hand, there are the relationships established among bioenergy producing companies and agricultural biomass suppliers-indirectly with large grain producers 
in the Region - the existence of which is more or less supporting the expansion/maintenance of areas with grain crops, to the detriment of other crops grown by Mapuche and farming communities.

The history of biomass plants in La Araucanía is quite brief. Their existence, from the initial proposal itself, has not always raised concerns among Mapuche and local farming communities, in spite of the reasons mentioned above. However, economic complements with farmers and Mapuche communities—like the one established with forestry activities and commercial agriculture-is highly impracticable. Impracticality and conflict are only a small step away.

As evidence from recent years has made clear, bioenergy is not always sustainable in terms of the environmental, economic and social aspects involved in its generation. It is only potentially sustainable. But effective sustainability requires operational efficiency, environmental impact abatement, economic feasibility and social acceptance.

In environmental terms, a poor bioenergy production system can be as damaging as an oil-based system [15]. In economic terms, a certain land ownership concentration is required. In Croatia, for example, with $52 \%$ of farmlands and between 733,780 and 3 million tons of farm waste for biomass-depending on the calculation method-the potential to develop bioenergy is minimal as $60 \%$ of farmers own less than 3 ha. In addition, there is little mechanization to collect biomass [16]. In terms of the social aspects, a no less important factor is the aversion of farmers themselves to replace or modify their ways by introducing crops or plantations for energy purposes-even if this involves higher economic benefits—as they prefer to keep their traditions and lifestyles [17].

Given all these aspects, it has even been suggested that the sustainability of bioenergy is low and that its contribution to global energy generation will never be to large [18]. In addition, the hopes placed on bioenergy as an alternative energy source have somewhat become thwarted. When calculating biomass potential for energy purposes, forms of use and effective energy generation, the obstacles involved in its development have emerged strongly.

One of these obstacles is the fact that the use of farm biomass is limited by its other uses, such as soil fertilizer and fodder. A maximum of $30 \%$ of farm waste can be used for the production of bioenergy. On the other hand, there is the competition of energy crops with food staples for land use. In response to this, progress has been made in the use of marginal lands for energy crops [19]. Only in China, there is an estimated 152 million ha of marginal lands.

Still another issue is the supply logistics of farm waste. Up to $90 \%$ of the cost of collecting biomass is logistics, with the rest being the cost of the harvest [20]. Due to this, the maximum space surrounding the bioenergy plant to source biomass is small. The adequate range considering European and Brazilian experiences is between 35 to $50 \mathrm{~km}$ [21]. Often, the concentration of biomass in a certain space is insufficient, raising transportation costs that involve an expanded area. This results in biomass plants being small and only covering local needs. A plant of a considerable size that can source farm and wood biomass from a broad area is simply not feasible.

There are successful biomass production cases but generation levels are low and benefits only accrue on a local scale [22]. Some of these cases are the agro-energy districts in certain areas of Greece and Italy, where major progress has been achieved by means of public-private partnerships [23-26]. Interestingly enough, these partnerships have been established under the recent economic crisis. Overall, bioenergy production requires land-based organization, considering several state, city and rural stakeholders.

The Chilean experience described in this article includes several organization approaches to bioenergy production. While there are no public-private partnerships for generation nor a macro-ecological and land-based planning of energy projects, the active participation of the state in the promotion and development of bioenergy projects cannot be ignored, even if their design and generation are solely private. On the other hand, the specific restrictions involved in bioenergy generation are also apparent in Chile.

This article intends to make a contribution to the understanding of bioenergy generation based on farm and wood waste, taking into account the specific historical constraints of this activity in Chile. 
The article further confirms most of the insights found in literature regarding the requirements that the activity must meet to be sustainable. In addition, it intends to complement such studies by suggesting that, along with the economic, technical, environmental and social aspects, historical constraints are also decisive in bioenergy development potential. In a unique region such as La Araucanía, with a broad productive, social and political crisis during the past decade; a long track-record of economic and social conflicts; grain farming under crisis due to commodity prices; and a forest activity called into question due to environmental impacts, the sustainability of bioenergy projects is increasingly limited.

\section{Materials and Methods}

This article is a historical study of bioenergy generation in La Araucanía, south of Chile, particularly focusing on the experience of Comasa, a company located in Lautaro. This company was the first to produce bioenergy in Chile with third-party supplied wood and agricultural biomass. Likewise, two new projects to produce bioenergy in the Region will be discussed. The study mainly relies on the projects submitted to the Environmental Assessment System by the companies; government censuses and statistics; information published by companies and state agencies; publications in regional media outlets; interviews with employees, entrepreneurs and experts linked to Comasa; field observations; and literature in general about the Region and the topics addressed.

Following a historical method, an explanation is sought about the emergence of bioenergy generation in the south of Chile using wood and agricultural biomass, asl well as establishing the relevance of the regional economy in the development of this new activity. First, the growth of renewable energy generation in Chile during the past few decades is shown, including the excellent business opportunities opening up for bioenergy production. Subsequently, the fundamental elements of the regional agroforestry economy are discussed, the activities of which produce abundant wood and agricultural biomass available for bioenergy generation.

Mainly, attention is drawn to the new relationships established between Comasa-the bioenergy generating company — and wood and agricultural waste suppliers. To understand this relationship, its brief history is summarized in terms of its organizational and planning aspects, which have involved major logistic and economic achievements. All of this is completed basically using testimonies by stakeholders directly involved in the consolidation of such a relationship (namely, the company, the government, trade organizations and suppliers) and information published by the company itself and in regional media outlets.

Concerning the historical methodology, the research underpinning this article considered all sorts of information sources to get a better understanding of the issue at stake. Given that the epoch under study is recent, sources are scarce but nonetheless sufficient to reach findings. Particularly important are the interviews made with relevant stakeholders in the history of bioenergy projects: the manager of the Comasa plant; the leader of the program who organized the farm suppliers; and the main entrepreneur in charge of procuring and hauling farm residues to the plant. All of them were submitted to a semi-structured interview in order to find out about the technical, economic, social and political aspects linked to the development of the experience studied in this article. Similarly, several field visits were conducted to the area of the Lautaro plant and to the supplying farm and forest areas around it. Figures and notes were taken, and there was a detailed reconnaissance of the space where the bioenergy project was being carried out, including type of properties, road conditions, location of plantations and forest industries, among other aspects.

Starting from 17 NCREs plants established between 2006 and 2010, 146 new plants were built between years 2014-2017, reaching a total of 253. Of these, 115 were small hydro plants, 71 solar plants, 30 wind farms and one geothermal plant. One of the most interesting phenomena occurred together with the irruption of NCREs in the past few years is the reduction in energy costs, which have dropped significantly from a maximum of US\$129 in 2012-2013 to US\$32.5 per MWh by the end of 2017. This poses new challenges for the electric power industry in general and for the production of 
bioenergy in particular, which has seen the plunge of electricity prices during the 2014-2017 period, the same term of the NCRE plant boom [27].

In Chile, bioenergy basically means biomass. Given limited areas of arable land, biofuel and biogas generation projects failed to succeed-with only one running on urban organic waste-and generation only involves electric power and steam from biomass. In early 2015, there were 19 biomass plants in Chile, with an installed capacity of more than $900 \mathrm{MW}$, of which about $470 \mathrm{MW}$ were introduced to the Central Interconnected System (CIS) [28-31]. This amount corresponds to $10.2 \%$ of the total CIS generation.

Biomass plants are located mainly in Chile's central and southern areas. They belong to large forest companies that produce energy taking advantage of their own waste, in what are called cogeneration plants. The oldest one in the industry is Arauco Bioenergía-a subsidiary of Arauco S.A.—which started operating at the beginning of 1988. It has eight plants that mostly feed its own industrial processes. By the end of 2015, it reached an installed capacity of $606 \mathrm{MW}$, contributing with $209 \mathrm{MW}$ of surplus energy to the CIS [32]. Another important company in the industry is Bioenergías Forestales, a subsidiary of paper and cardboard manufacturer Compañía Manufacturera de Papeles y Cartones. It has four plants with a $390 \mathrm{MW}$ capacity [33].

The exception is Energía Verde S.A, owned by the power firm AES Gener, which started producing electric power for forest companies in Constitución and Laja in 1995, using their own waste [34]. All of these plants were located in the country's central and south region and they were mostly small plants, with four medium-sized ones. Almost all were cogeneration plants closely linked to forest activities and owned by forestry-related companies (i.e., manufacturers of paper, cardboard, pulp mills). Besides AES Gener-already mentioned as an exception and which offers cogeneration services to forest companies-Comasa is a very different case within this group of firms. It is the first bioenergy company to produce electric energy in a strictly standalone fashion, purchasing both wood and agricultural biomass from third-parties.

On the other hand, the areas where bioenergy was mainly being produced using biomass were the Regions of Maule, Bío-Bío and Los Ríos. The Region of La Araucanía, which began production in 2011, was at such point a broad and largely untapped territory in terms of bioenergy.

The delay in introducing bioenergy production in La Araucanía can be explained by historical and productive conditions specific to this Region. While forestry gained a leading position in the Maule, Bío-Bío and Los Rios economies during the previous decades-with an increase in pine and eucalyptus plantations and the setting up of timber, pulp and paper mills—and progressed considerably also in La Araucanía, traditional grain farming and livestock operations have strongly prevailed in the latter Region. [35,36].

During the 20th century, La Araucanía - particularly the northern Malleco Province-used to be known as Chile's breadbasket. This Region traditionally produced the wheat consumed in the country, asl well as most of its oats. Similarly, the area has also been a major producer of barley, peas, potatoes and beans, among others, added to a strong cattle-raising activity, including both bovine and ovine. Finally, native forest logging operations are also relevant, particularly in the pre-mountain area of the Province of Cautin. This was evidenced by a large number of sawmills and timber production plants spread throughout the area.

On the other hand, La Araucanía is the land of Mapuche indigenous communities. After the population who settled in Santiago, the largest share of Mapuche indigenous peoples has for long inhabited this Region. By 1929, there were 2452 Mapuche communities, with 423,000 ha allocated by the State in the former decades [37]. With the pass of time, the populations of the original communities-close to 75,000 people-increased considerably and spread through the country. Today, most of these communities live and occupy the Region. As of 2013, an estimated 32\% of the Region's population was of Mapuche descent, i.e., 309,952 people [38]. Similarly, there is a considerable amount of medium and small landholdings resulting in a large number of small farmers, most of them descending from Chilean and foreign settlers who came to the area as of the end of the 19th century. 
According to the agriculture, livestock and forestry census of 2007, in Chile there were 479,404 ha of grain crops [39]. La Araucanía was the region with the largest planted surface area, 169,610 ha. In spite of a considerable reduction in surface areas with wheat crops, the Region continued to be "Chile's breadbasket". Also outstanding was an increase in oat crops [40] and major surface areas allocated to fodder crops $(90,047 \mathrm{ha})$, legumes and tubercles $(15,373 \mathrm{ha})$ and fruit trees $(12,618 \mathrm{ha})$. In addition, there were 668,140 head of cattle, the second largest in terms of cattle head after Los Lagos. The number of sheep amounted to 277,884. Most of the livestock in the Region was located in the southern end, in the Province of Cautín. The Region boasted the fastest growth in terms of forest plantations, increasing from 141,522 to 588,250 ha between 1976 and 2007. It ranks second at the national level after the Region of Bío-Bío. Additionally, by 2008 there were 937,312 ha of native forests [41].

In La Araucanía, crops cover the Region's center and southeast areas, prairies the central and south areas, and the north, northwest and pre-cordillera areas are planted with exotic and native forests. Thus, the Region's economy is characterized by forestry, agriculture and livestock. Concerning crops, in the past decades there has been a considerable reduction in legumes (particularly beans and lentils), but potatoes have increased their yield significantly. Although with a reduced surface area, grains are still decisive in the Region's economy-with large-and mid-sized landholdings. Surface area reductions have been offset with an increase in the yields of wheat, oats, barley, rye and maize. Likewise, industrial crops (rapeseed, lupine and beet) have maintained a similar surface area but boosted their yields, increasing their output many times.

Livestock has kept its traditional relevance, particularly beef. The opposite is true for milk production, which has been decreasing in the past few years. Beef production is the industry most hardly hit by the increase in meat and dairy imports.

Within the Region, the Province of Malleco (the Region's northern area) faces the greatest difficulties due to declines in traditional agriculture and fast-growing forest plantations. On the other hand, diverse agricultural activities and livestock farming are carried out in the Province of Cautín, although forest areas have also increased. In addition, in the entire Region-but particularly in Cautín-fruit crops have been developing, including apples, berries, European hazelnuts and vineyards, among others.

In the past few decades, the decline in traditional agriculture and the expansion of forest plantations has mainly impacted the large number of rural and indigenous inhabitants in the Region. An example of this is that the majority of the Region's population lives under poverty conditions. In 2013, the average national poverty rate stood at $14.4 \%$, while in La Araucanía it was $27.9 \%$, the highest in the country. In terms of multidimensional poverty (which includes indicators on education, health, employment, social security and housing), the national average was $20.4 \%$, reaching $28.5 \%$ in La Araucanía. If only the Region's rural population is considered, the figure exceeds $40 \%$ [ 42$]$.

The already high rural income poverty levels in La Araucanía were even higher in some municipalities. In 2013, the largest income poverty was found in rural communities: 50.7\% in Nueva Imperial; $50.4 \%$ in Perquenco; $48.6 \%$ in Lumaco; $47.6 \%$ in Teodoro Schmidt, $33.4 \%$ in Lautaro, $33.1 \%$ in Vilcún and $30 \%$ in Traiguén. The municipalities with the lowest poverty levels were those with mostly urban residents, namely: Villarrica, Temuco, Angol and Victoria [43]. Additionally, the poorest municipalities are often those with a majority of Mapuche inhabitants.

Consequently, La Araucanía is undergoing widespread political, economic, social and environmental conflicts involving indigenous Mapuche communities-who claim the lands taken by the State-individuals and, recently, forest companies. [44]. Similarly, they oppose to productive activities and economic projects that impact the resources and the lands they inhabit, asl is the case of forest plantations, power plants-either hydro or thermal-and pulp mills, among others [45]. Specifically, the issue implicates the State, which has been unable to address the situation in all its complexities. 
In this Region—strained by an agro-forestry productive model under crisis and with farming and Mapuche communities negatively impacted by the neo-liberal developments of the past few decades-bioenergy generation does not come as a neutral matter but is tainted by all the aspects mentioned above. From a corporate and economic standpoint, the Region of La Araucanía offers an excellent opportunity to produce energy based on wood and agricultural biomass.

While bioenergy production with biomass developed strongly in the Bío-Bío and Los Ríos regions since 1996, after the setting up of cogeneration plants adjacent to pulp mills, these types of projects were missing in most of La Araucanía until 2010. In addition to the growth of the forest industry, which produced large amounts of residues from sawmills and logging, significant harvests in the Region left a huge amount of agricultural waste. Perhaps no other region was as suitable for bioenergy generation as La Araucanía.

Overall, in Chile's center and south region there is a major surplus of wood and agricultural waste every year, most of which remained untapped until the setting up of biomass plants [46-48]. For the 2003-2004 season, agricultural residues generated were estimated at 72,325,704 ton. La Araucanía was the second region in terms of waste volume, after Bío-Bío, with 1,529,900 ton, resulting from wheat, oats and potatoes. This amount includes 622,000 ton per year of wheat straw [49].

On the other hand, for 2005 it was estimated that the entire country generated 3,253,724 ton of forest waste, of which $56.2 \%$ were sawdust, $15.1 \%$ bark and $12.2 \%$ slab wood, among the main ones. Out of the national total, the Region of La Araucanía produced 371,045 ton.

The most abundant source of biomass in the Region comes from agricultural residues, exceeding four times the waste coming from the forest industry. In addition, in 2013, the potential surface area in Chile's central and south region to establish plantations-particularly eucalyptus-for biomass production was estimated in 383,755 ha. The potential surface area in the La Araucanía Region alone was 68,772 ha [50]. All of this points to the fact that bioenergy from biomass in the La Araucanía had actual grounds for greater development. A further consideration is the significant demand for electric power from the Region's companies and large urban hubs. As of 2017, the Region's population amounted to 957,224; Temuco, the capital city, had 282,415 inhabitants. The rural population amounts to $29.1 \%$, and $34 \%$ considers itself as Mapuche [51].

Undoubtedly, both the existence of forest and agricultural waste plus significant demand are only the basic elements of any project's feasibility. Besides that, ensuring a constant and adequate supply of biomass - in terms of volume and quality-is decisive. All of this is expected to be achieved at low costs, meaning that the biomass has to be produced in a close range to the bioenergy plant. Thus, forest and agricultural residues as feedstock become critical in ensuring the feasibility of any bioenergy project. And while biomass procurement logistics are easily managed in the case of the forest industry, this is not the case in standalone generation projects.

\section{Results}

\subsection{The Comasa Experience}

As mentioned above, out of a total 19 biomass plants existing in 2015, the exception is Comasa-a subsidiary of Forestal y Papelera Concepción (FPC). This company has two bioenergy plants, both of which are nearby Lautaro. One of them uses wood and agricultural biomass and the other, exclusively agricultural biomass. It is the first standalone, non-cogeneration energy production experience in Chile that purchases third-party wood and agricultural inputs and supplies its entire energy production to the CIS [52].

The experience of the company that owns Comasa began in 2005, after the boost in electric power prices due to the reduction in Argentinean gas supply mentioned above [53,54]. In 2006, FPC setup a cogeneration plant using its own wood biomass and biomass purchased from sawmills and local forest companies, which it ended up selling. Finally, through Comasa, a former biomass supplier, it launched the project in Lautaro [55,56]. The first studies for this project began in March 2008. 
Prior to the construction of the Lautaro plant, Comasa S.A submitted the project to an environmental assessment on 6 November 2009, under the name "Lautaro Renewable Energy Generation Project" [57]. The project's title-which stresses its renewable nature-is of relevance, asl it anticipated government approval in view of the scenario described above.

The project claimed that the proposal followed the Clean Development Mechanism defined under the Kyoto Protocol, which involved the promotion of emission reduction projects in developing countries. In this case, this goal was achieved by the use of biomass as a renewable resource. The plant was expected to reduce greenhouse gases by 78,000 ton of carbon dioxide $\left(\mathrm{CO}_{2}\right)$. In addition, it was also proposed as following a national Act of 2008 which addressed the country's need to increase energy production based on renewable sources. The project included the installation of a boiler expected to use untreated wood agricultural biomass (sawdust, shavings, bark, wheat straw and oats hull). One hundred percent of the biomass would be purchased from third-parties and transferred to the plant by truck. As estimated, 321,872 annual ton of wood biomass would be used, coming from sawmills and forest activities, and 25,727 annual ton of agricultural biomass, namely: wheat straw and oats hulls. This was expected to generate $25 \mathrm{MW}$, of which $23 \mathrm{MW}$ would be introduced to the CIS.

There were major reasons to locate the plant in Lautaro. On the one hand, the site was at the center of an extended forest and agricultural area, facilitating the procurement of the required biomass. In addition, it was no more than $100 \mathrm{~km}$ away from the biomass plants located both to the north and south. Finally, since there was an electric substation in the vicinity, investments required to supply the energy produced to the CIS were expected to be limited.

As the area is inhabited by indigenous communities, asl indicated above, the project highlighted that it was not adjacent to indigenous lands; the closest community to the north was located $4 \mathrm{~km}$ away, while to the south, the closest one was $8 \mathrm{~km}$ away. On 11 March 2010, the Environmental Committee of the La Araucanía Region approved the project, ratifying that it met all environmental regulations.

The Comasa plant began to operate in August 2011. To the wood and agricultural biomass, 30,000 cubic meters of firewood were added in 2012, which required the installation of dryers. Apparently, this was done with a very specific aim. In June 2012, the company made efforts to be recognized as a cogeneration and not a generation plant. A cogeneration plant differs from a generation plant in that it produces thermal power for a productive process, with electricity being a surplus of the leftover energy used in the industrial activity itself. On the other hand, in generation plants (the case of Comasa), the steam generated from the burning of biomass becomes electricity to be supplied to third-parties.

The problem for Comasa was that, in 2011, the Chilean Ministry for the Environment approved new emission standards for thermoelectric power plants requiring the reduction of particulate matter and gases in plants of 50 or more thermal megawatts, with the exception of boilers that were part of cogeneration plants. In the case of Comasa, drying firewood with boiler steam would be part of a cogeneration process. Therefore, the request was denied.

In sum, bioenergy production was successful. Wood biomass was collected from large sawmills and timber industries in close range, and agricultural residues from a small group of businesses (30,000 bales of 500 kilos each). These bales—of considerable size and weight—needed to be baled with special machines (baling machine and tractor) purchased by the company in the US and Chile, and offered to its suppliers under credit conditions [58].

The possibility of accessing a larger volume of agricultural residues-with more heating power than wood waste-as well as higher electric power prices, led Comasa to design a second plant to generate electricity based exclusively on agricultural biomass. The project was submitted to environmental assessment in October 2012, under the title "Grain Straw Energy Use in Renewable Energy Plant, Unit No.2" [59]. The proposal included the generation of 22 MW using agricultural biomass - of which $20 \mathrm{MW}$ would be introduced into the CIS - under similar technical conditions as Plant No.1. This energy would be generated using 131,400 annual ton of grain straw. Eventually, $5 \%$ of wood biomass would be used. 
These figures suggest that agricultural biomass is much more efficient than wood biomass, asl 2.6 times less ton of biomass generate a similar amount of electric power: $26 \mathrm{MW}$ in Plant No. 1 with forest and agricultural biomass; and $22 \mathrm{MW}$ in Plant No. 2, with agricultural biomass only. The project highlighted that the use of agricultural biomass would prevent the burning of residues in the fields which would otherwise result in annual emissions of 1,095 ton of particulate matter and 73,040 ton of $\mathrm{CO}_{2}$.

Unlike in the first project, it was indicated that in this project the nearest indigenous community was located $2.6 \mathrm{~km}$ to the north. Formerly, it had been stated that the community was located at a distance of $4 \mathrm{~km}$.

During the environmental assessment process, 10 people expressed their concern before the Environmental Assessment Service in the La Araucanía Region, eight of them Mapuche. Their claims were related to the plant's noise, foul odors and smoke emissions; and to the increase in water use to run two plants.

The project further explained that the grain straw supply—a byproduct of grain harvests—would be obtained between January and May. Each supplier was to deliver the straw in bales with specific dimensions-2500 $\mathrm{mm}$ long, $900 \mathrm{~mm}$ high and $1200 \mathrm{~mm}$ wide-and transferred in trucks to the plant at their own expense. The bales are stockpiled during those months and for the whole year in a 6-ha plot. The project was finally approved in April 2013 and the second plant began its operations in April 2014. Thus, Comasa's two plants managed to produce $48 \mathrm{MW}$, which were mainly introduced into the CIS (Figure 1).

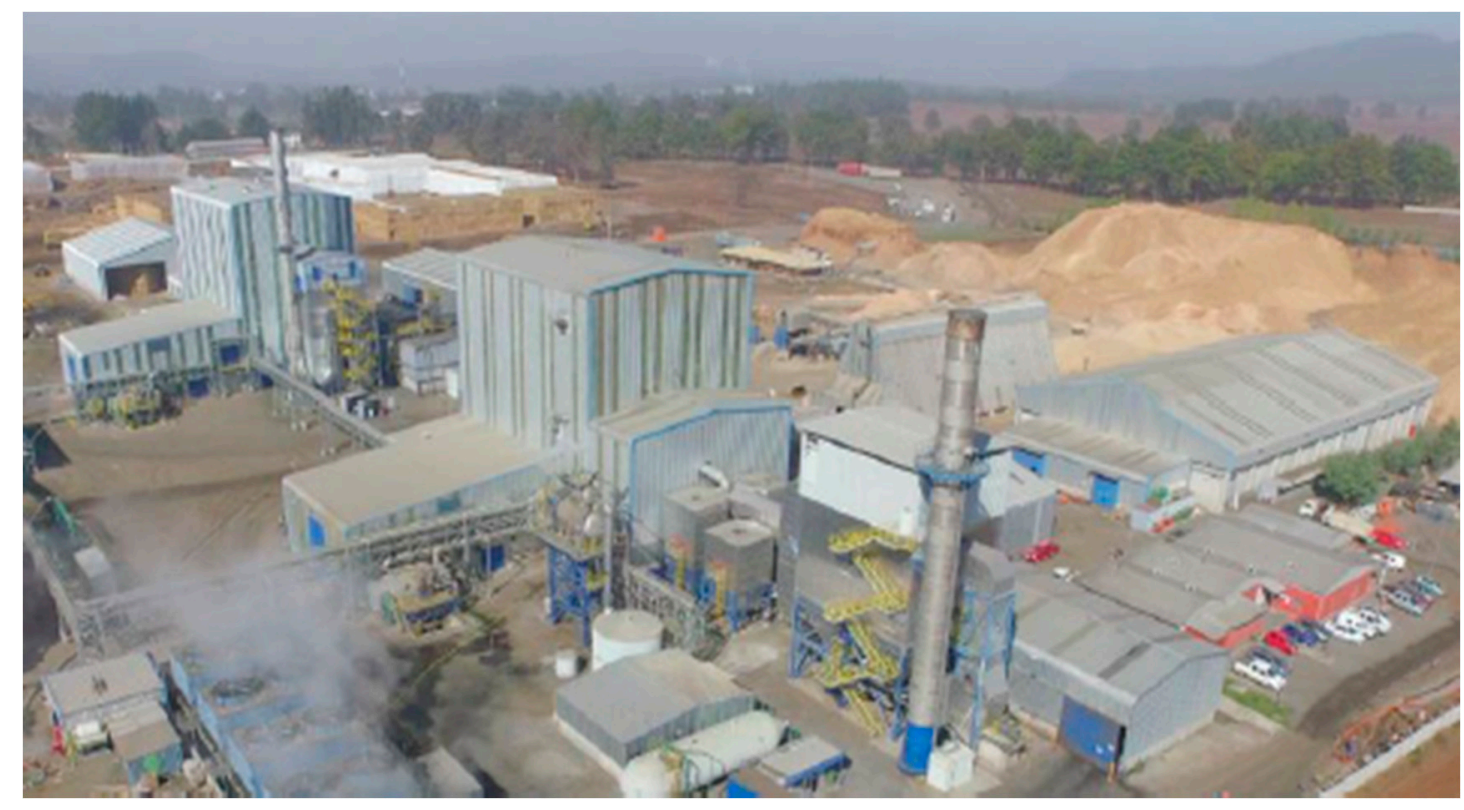

Figure 1. Comasa Plants 1 and 2, Lautaro [60].

The business was a promising one. Already in 2013, Comasa had sold all the power produced in Plant No. 1 to Colbún, one of the country's largest power generators which is forced to produce or purchase shares of NCREs under the 2008 Act [61]. From the beginning, Comasa has highlighted that it produces green, renewable and clean power in its Lautaro plants. Likewise, it stresses that its demand for biomass means a contribution to local economies as it uses residues from the forest industry and grain harvests, which would otherwise remain unused or be burnt on field polluting the environment.

By January 2015, the company had 12 large biomass suppliers, including sawmills, lumber companies, agricultural entrepreneurs and farm service providers. Some of the agricultural biomass suppliers obtained the biomass from their own harvests but most of them collected it from local farmers, 
baling and transporting the straw to the plant. The baling process required high-cost specialized machinery, reason for which Comasa assisted the suppliers with credits for their procurement.

The need to improve the logistic efficiency for the supply of wood and (particularly) agricultural biomass led to the development of a Supplier Development Program (SDP). This SDP was implemented by the Society of Agricultural Promotion (SOFO) - the main farmers' association in La Araucanía-with the support of the Chilean Economic Development Agency (CORFO), which has undertaken the promotion of new energy production $[62,63]$.

The program started following a contact between SOFO and Comasa, in 2014. At such point, the company was facing issues related to the supply and management of agricultural biomass; bale quality; transportation costs and scheduling and delivery to the plant; and stockpiling of bales in the plant, among others. The main issue concerning forest suppliers was related to improving the handling of the byproduct before the delivery to Comasa in order to prevent moisture-related damages.

The SDP—implemented between 2015 and 2017—was designed to improve the efficient and constant supply of biomass. A Web platform was created to establish an adequate means of communication between Comasa and its suppliers. The platform improved the scheduling of bale delivery to the plant; collected information on the baling process; and detailed the payment terms. On the other hand, unloading and stacking of the bales was optimized; bale production began to be georeferenced on field; and bale collection was scheduled based on the local field burning schedule to prevent fire-related damages. Furthermore, the German company Verschoor-experts in straw baling-provided the suppliers with technical assistance on the baling process and baler maintenance in order to guarantee that bales met the required dimensions and quality standards. (Figure 2). Training for wood biomass suppliers was in charge of Teknip, a company devoted to the sale of forest industry technology.

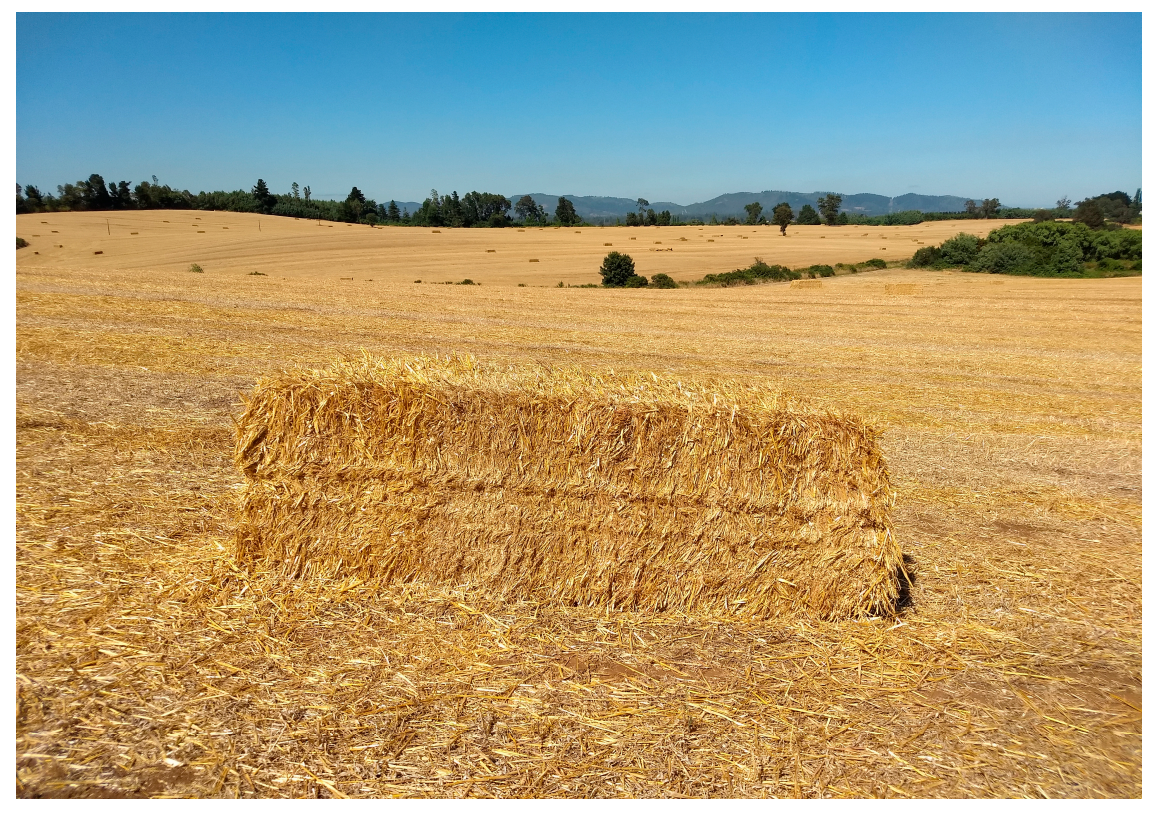

Figure 2. Field outside Lautaro, March 2018. Source: Author's own record.

Finally, the number of suppliers increased from 12 to 18, which also increased the total volume of wood and agricultural biomass delivered to Comasa. The need for a specialized baling machine-with a cost of US\$120,000 — and of at least one tractor (with a similar cost), restricted the growth in the number of suppliers; but, the number of available suppliers provided sufficient agricultural biomass. Overall, suppliers use approximately 25 baling machines which, asl stated above, were originally purchased by Comasa and then sold, leased or loaned to the biomass suppliers. 
The maximum range of operations of the suppliers is about $70 \mathrm{~km}$ from the plant. Beyond that distance, costs rise. Ultimately, Comasa is collecting agricultural biomass from a broad area around Lautaro; Ercilla, Victoria, Vilcún and Nueva Imperial, while wood biomass comes from a closer distance. During a regular season, 220,000-240,000 bales are delivered to the plant; i.e., a maximum of about 120,000 ton (Figure 3). This agricultural biomass volume comes from a crop surface area of $35,000-40,000$ ha. Considering the total surface area planted with grains in the Region, three bioenergy generation plants running on agricultural biomass could well be installed in the area.

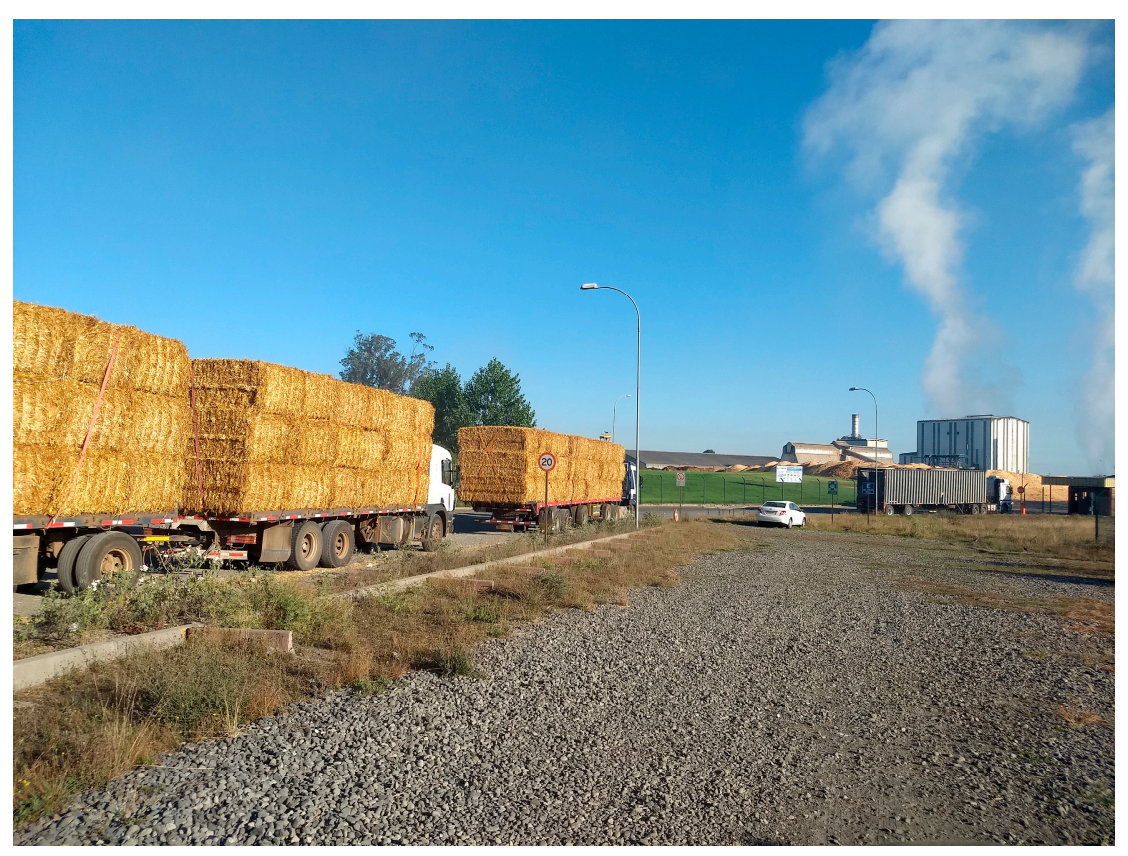

Figure 3. Bales delivered to the Comasa plant, March 2018. Source: Author's own records.

Comasa pays approximately US $\$ 13$ for every $500 \mathrm{~kg}$ bale, amounting to a maximum total spending in bales per season of US\$3.12 million. This expenditure amounts to $40 \%$ of the plant's total operating costs. In a simple calculation, this would amount to US\$7.8 million in expenditures to produce $22 \mathrm{MW}$; or what is the same, US $\$ 40.47$ per MWh. These production costs are below the average marginal cost for year 2017, which amount to US\$57.23 per MWh [64]. While profitable, these margins are not overly confortable.

\subsection{New Bioenergy Projects in La Araucanía. Opposition from the Local Community}

Some estimates suggest that La Araucanía has a biomass-based bioenergy generation potential of up to $103 \mathrm{MW}$, only considering available wood biomass. Taking into account that each Comasa plant generates slightly over $20 \mathrm{MW}$, there is room for the development of several more plants with similar power. In addition, if the agricultural biomass available in the Region is used, asl we have discussed before, there is also an additional margin for three or four extra plants similar to Comasa's Plant No. 2. Those are precisely the efforts that have been undertaken in the past few years. While two new bioenergy plant projects have been approved, both have faced less favorable contexts.

One of the projects-called "Agricultural Biomass for Energy Generation, Region of La Araucanía" - was submitted by Rakun SPA to an environmental assessment in November, 2014 [65]. The project considered the installation of a bioenergy plant to generate $30 \mathrm{MW}$ in the south section of the Freire commune, near the main highway, midway between the cities of Freire and Pitrufquén. This was the largest project in terms of investments in La Araucanía, with an US $\$ 85$ million budget. It expected to use only agricultural biomass from grains (straw) found in the plant's vicinity (a range 
of $50 \mathrm{~km}$ ), amounting to 120,000 ton per year (400,000 bales weighing 400 kilos each). The project highlighted the benefits for farmers involved in removing agricultural residues, favoring crop rotation.

According to the proposal, the plant was expected to be located in an unpopulated area thereby preventing any impact on people and the environment. It acknowledged, however, that there were two nearby Mapuche communities: one located $1300 \mathrm{~m}$ to the east and the other $550 \mathrm{~m}$ north. During the environmental assessment process, local Freire residents-particularly members of the two indigenous communities-requested further studies claiming that the plant would impact their quality of life. The project simply overlooked local populations and the farming activities carried out by them.

To address local opposition, Rakun organized a tour to Comasa for the community and officials with the Municipality of Freire so that they could understand the operation of that plant, which is similar to the one under study. Criticism, however, continued. In 2015, the National Human Rights Institute (INDH) qualified this project as a socio-environmental conflict that faced the company with local dwellers, indigenous communities and the Municipality of Freire [66]. In spite of all this, the political will of national and Region's officials was stronger than the weaknesses of the Rakun project, which was approved by the Region's Environmental Committee in January, 2016. The resolution explicitly stated that the project did not entail any risks for the health of the population or impacts on their activities. Nor would there be damage to the Toltén River due to liquid waste discharges.

Finally, Rakun itself abstained from implementing the project, which was notified to environmental authorities on 30 April 2018 [67].

The second biomass project is operated by Energías Victoria SPA [68] and was submitted for environmental assessment in June 2016. The project involved installing a $20 \mathrm{MW}$ bioenergy plant running on agricultural biomass, of which $17 \mathrm{MW}$ would be fed into the CIS. Up to $30 \%$ wood biomass could also be used in the form of wood chips. The plant was expected to be located $3 \mathrm{~km}$ away from the city of Victoria, in the northern area of La Araucanía, very close to the highway. An indigenous community lives on a 200-ha plot in the plant's vicinity. According to community members, the company consulted with them during all the stages of the project's design, reason for which they were satisfied with the initiative [69]. Although the project was approved in March 2017, the owner company has been perfecting it before its implementation, including looking for suppliers and adapting the processes to maximize efficiency, given the drop in electricity prices.

\section{Discussion}

In the Comasa experience, the close relationship among grain farmers, forest entrepreneurs and enterprise, points to an interesting link among bioenergy generation, traditional grain farming and forestry in La Araucanía. Interestingly enough, Comasa puts emphasis on its bioenergy condition involving clean and renewable energy - all aspects aimed at being developed under today's economy - while its suppliers pertain to grain farming - an activity that has faced tremendous difficulties-and forestry, an industry strongly called into question due to social and environmental damage (water reduction and negative impacts on household subsistence farming). Likely concerns regarding the future feasibility of bioenergy generation with such weak foundations are certainly valid.

On the other hand, while the sale of biomass is not such a great business for farmers and forest entrepreneurs in economic terms, the removal of agricultural residues from the fields does mean savings for farmers as it prevents field burning or facilitates soil preparation, all of which improve future harvests. General benefits also result for crops by the side of the road, beside high voltage cables or near suburban areas, where field burning is forbidden. Furthermore, the sole claim by agricultural and forest entrepreneurs concerning their contribution and current involvement in the production of bioenergy is socially valuable and needs to be acknowledged. In this sense, the close and strong ties between agricultural and forest businessmen and Comasa entail highly convenient, long-term and profitable benefits. In this relationship, agricultural service providers play a major role as intermediaries between producers and Comasa. 
While the company has relied on government support-particularly from the regional government-and on large-scale local farmers, the local community feels quite dubious about its alleged environmental contributions. Between 2012 and 2016, Miguel Jaramillo, the Mayor of Lautaro, had a distant relationship with the company as he saw no benefits for the commune, and even believed it had negative environmental impacts. Additionally, he disliked the expansion of Comasa activities in a second plant and questioned its actual contributions [70,71]. A fire in 2014 that burnt down all of the straw bales stockpiled in the plant was a further event for the Mayor to oppose the company [72].

To keep good relationships with the local community, Comasa has followed a constant open doors and transparency policy, mainly including guided tours to the plant for specific groups of students and farmers. Furthermore, it is aiming at minimizing the plant's pollution with a project to return the ashes generated to its farm suppliers on the field [73].

In the case Rakun, beyond the planning required for its implementation, which delayed commissioning, the project's development faced strong opposition [74,75]. Opposition from local communities, particularly the Mapuche, was outright, rejecting the installation of what they called "thermoelectric plants". The expression had an inevitable negative sense as it was instantly associated with pollution. It is definitively not the same as talking about "bioenergy". The opposition increased when the project was approved. The Mapuche media reported the fact sanctioning: "Plundering continues. The La Araucanía Region's Government approved a thermoelectric power plant in Freire" [76].

The project was seen as negative because bioenergy production required huge amounts of water from a deep well-30 L/S - precisely next to both indigenous communities. In addition, it was stressed that the company's project overlooked the importance of being close to the Mapuche communities. On top of that, part of the capital behind the project was Canadian, which gave detractors a further argument. Additionally, the local media did not believe there could be a non-polluting thermoelectric power project, putting emphasis on particulate and gas emissions that would be released by the plant and harm nearby populations. The media talked about looting, recalling that this project was similar to many other initiatives approved by the State in La Araucanía since 2006 onwards, namely: 14 hydroelectric power plants; six wind farms; four thermoelectric and one geothermal power plant. All of this added a power of $1500 \mathrm{MW}$, much more than the Region's total demand. Allegedly, the projects were to serve large-scale mining and industries operating in other regions [77].

In order to avoid the issues faced by Rakun and just like Comasa, Energías Victoria has taken measures to communicate the plant's benefits to the community, for instance the use of 120,000 ton of straw which would otherwise pollute the area if burnt. However, the delay in implementing the project raises questions that it can share the same fate as the former project. This is the concern aired by the Mayor of Victoria, Javier Jaramillo, when in early July 2018 he reported to the press that he was in contact with Energías Victoria, asl well as with another company interested in developing a wind farm, to express his support and request the materialization of both projects [78].

\section{Conclusions}

Bioenergy generation from biomass has grown quickly in Chile's center and south regions since the nineties onwards, amounting to 19 plants at present. Most of these are cogeneration plants fed with wood biomass. The increase in energy prices since the mid-2000s enabled a different type of bioenergy generation, which entails purchasing the wood and agricultural biomass from third-party suppliers, i.e., nearby forest and agricultural companies.

These plants have a considerable potential as they use residues from the forest industry and grain crops. This potential led to the installation of two bioenergy generation plants in Lautaro, La Araucanía, by company Comasa. This successful project has resulted in a favorable relationship between the bioenergy plant and the forest and agricultural industries, with biomass supply organized efficiently within a maximum range of $70 \mathrm{~km}$. This has led to complements between Comasa and forest and farm businesses, intermediated by the suppliers. While the Comasa plant has low-cost biomass, forest and 
farm businesses favor their productive processes, soil cleanness and crop rotation, and are seen as linked with clean production.

The pillars that uphold bioenergy production may, however, lack stability. Grain crops have contracted heavily in the past few decades and there are many other crop and plantation options. The expansion of the forest industry, on the other side, has ensuing impacts on water availability, biodiversity and the livelihoods of farmers and indigenous communities. A full-scale political, economic and socio-environmental crisis is unfolding in La Araucanía, expressed in high poverty rates and in the conflicts between the State and indigenous communities, asl the Mapuche hold the State accountable for their situation.

Following Comasa's example of a profitable bioenergy generation model from agricultural biomass, two other projects emerged in the Region: in Freire and Victoria, i.e., $51 \mathrm{~km}$ south and $36 \mathrm{~km}$ north of Lautaro. Both projects were approved by environmental officials but the first one was abandoned by its titleholder, Rakun, and the other is yet to be materialized. The Rakun project-to be located in Freire-was not implemented due to conflicts between the company and two nearby Mapuche communities, which received widespread support from the local population. Unlike Comasa, Rakun failed to establish good relationships with the local community depriving the project of a critical implementation factor. In addition, there is increased social awareness concerning the uncontrolled increment of energy projects in the Region, with questionable benefits for nearby populations. This has particularly resulted in across the board rejection of new "thermoelectric" power plants in La Araucanía. Unlike the case with Rakun, Victoria's project secured the support of indigenous communities early on. Apparently, however, it has been unable to adequately solve the logistics required for its implementation.

An important issue that is preventing the feasibility of new projects and even the continuation of existing bioenergy plants is the sharp decline in electric power prices in the past few years. Without considerable levels of profitability-something that seems unlikely-there is little encouragement for the development of new bioenergy generation projects fed on wood and agricultural biomass.

This article has ratified some of the topics already suggested in the literature concerning bioenergy and sustainability, particularly, the little sustainability of bioenergy projects. It is not true that bioenergy is always clean energy. This will depend on the specific conditions under which each project is developed. Technical and economic feasibility are not conditions enough to establish a plant, asl proven by the failure of Rakun. However, the experience by Comasa shows that sustainability can be reached based on a project that considers the different aspects involved. Specifically, part of Comasa's success has been the suppliers' program, which has solved some of the most fundamental aspects in a project's economic and social feasibility. Importantly enough, this could not have been done without the support of the state, through CORFO and SOFO.

Similarly, bioenergy generation in La Araucanía can lead us to acknowledge the importance of social acceptance for these types of projects; without social acceptance they cannot be sustained. There are important local differences in this aspect. In spite of the opposition expressed by the major, the community of Lautaro accepted the plant; while in the same Region, the community of Freire rejected even the idea of a plant in its area from the project's design. On the other hand, there is not much information regarding the stance of the community of Victoria, where there is a project under development, and apparently, they are accepting this future plant.

Finally, one of the contributions of this article has been to reveal the importance of the history of the areas proposed for plant installation in the sustainability of bioenergy projects. The generation of bioenergy takes place in a specific territory and historical moment and both are decisive factors in a project's origin and development. La Araucanía is a unique case: a Region plagued by historical conflicts among Mapuche communities, forest companies, farmers and the state. In addition, in the past few decades this conflict has escalated into an across-the-board productive, social and political crisis that leads to no optimistic view regarding the future of bioenergy in the Region. At least not of bioenergy projects imposed by companies-with state support-on local communities. Possibly, 
the road to follow would be to strengthen land-based planning of bioenergy generation with the agreement of all stakeholders involved, asl well as the development of smaller-scale bioenergy projects with local communities as both leading actors and main beneficiaries.

Funding: This research was funded by The National Fund for Scientific and Technological Development (FONDECYT), research project: "Internationalization and Transnationalization in Agroforestry Economy of Southern Chile, 1985-2010" (Number 1160321).

Acknowledgments: The author wants to express his gratitude to the editors and reviewers for their valuable comments and suggestions.

Conflicts of Interest: The author declares no conflict of interest. The funders played no role in the design of the study; in the collection, analyses, or interpretation of data; in the writing of the manuscript, and in the decision to publish its findings.

\section{References}

1. Wang, L. (Ed.) Sustainable Bioenergy Production; Taylor Francis Group: Boca Raton, FL, USA, 2014; ISBN 978-1-4665-0556-8.

2. Long, H.; Li, X.; Wang, H.; Jia, J. Biomass resources and their bioenergy potential estimation: A review. Renew. Sustain. Energy Rev. 2013, 26, 344-352. [CrossRef]

3. Poltronieri, P.; D'Urso, O.F. Biotransformation of Agricultural Waste and By-Products. The Food, Feed, Fibre, Fuel (4F) Economy; Elsevier: Amsterdam, The Netherlands, 2016; ISBN 978-0-12-803622-8.

4. Breunig, H.M.; Huntington, T.; Jin, L.; Robinson, A. Temporal and geographic drivers of biomass residues in California. Resour. Conserv. Recycl. 2018, 139, 287-297. [CrossRef]

5. Colantoni, A.; Delfanti, L.; Recanatesi, F.; Tolli, M.; Lord, R. Land use planning for utilizing biomass residues in Tuscia Romana (central Italy): Preliminary results of a multi criteria analysis to create an agro-energy district. Land Use Policy 2016, 50, 125-133. [CrossRef]

6. Zhao, X.; Cai, Q.; Li, S.; Ma, C. Public preferences for biomass electricity in China. Renew. Sustain. Energy Rev. 2018, 95, 242-253. [CrossRef]

7. Ozturk, M.; Saba, N.; Altay, V.; Iqbal, R.; Hakeem, K.R.; Jawaid, M.; Ibrahim, F.H. Biomass and bioenergy: An overview of the development potential in Turkey and Malaysia. Renew. Sustain. Energy Rev. 2017, 79, 1285-1302. [CrossRef]

8. Naqvi, S.R.; Jamshaid, S.; Naqvi, M.; FArooq, W.; Niazi, M.B.K.; Aman, Z.; Zubair, M.; Ali, M.; Shahbaz, M.; Inayat, A.; et al. Potential of biomass for bioenergy in Pakistan based on present case and future perspectives. Renew. Sustain. Rev. 2018, 81, 1247-1258. [CrossRef]

9. Simangunsong, B.C.H.; Sitanggang, V.J.; Manurung, E.G.T.; Rahmadi, A.; Moore, G.A.; Aye, L.; Tambunan, A.H. Potential forest biomass resource as feedstock for bioenergy and its economic value in Indonesia. Forest Policy Econ. 2017, 81, 10-17. [CrossRef]

10. Namuncura, D. Ralco: ¿Represa o Pobreza? Ediciones Lom: Santiago de Chile, Chile, 1999; ISBN 9562821811.

11. Sohr, R. Chile a Ciegas. La Triste realidad de Nuestro Modelo Energético; Random House Mondadori: Santiago de Chile, Chile, 2013; ISBN 9789568410636.

12. Mancilla, S. La Crisis Energética en Chile; Ril Editores: Santiago de Chile, Chile, 2009; ISBN 9789562846608.

13. García, C.J. (Ed.) Economía y Energía. La Experiencia Chilena; Ediciones Universidad Alberto Hurtado: Santiago de Chile, Chile, 2015; ISBN 9789563570502.

14. Pacheco, M. (Ed.) Revolución Energética en Chile; Ediciones UDP: Santiago de Chile, Chile, 2018; ISBN 9789563144123.

15. Paolotti, L.; Martino, G.; Marchini, A.; Boggia, A. Economic and environmental assessment of agro-energy wood biomass supply chains. Biomass Bioenergy 2017, 97, 172-185. [CrossRef]

16. Bilandzija, N.; Voca, N.; Jelcic, B.; Jurisic, V.; Matin, A.; Grubot, M.; Kricka, T. Evaluation of Croatian agricultural solid biomass energy potential. Renew. Sustain. Energy Rev. 2018, 93, 225-230. [CrossRef]

17. Gowan, C.; Kar, S.; Townsend, P. Landowners' perceptions of and interest in bioenergy crops: Exploring challenges and opportunities for growing poplar for bioenergy. Biomass Bioenergy 2018, 110, 57-62. [CrossRef]

18. Gupta, V.; Tuohy, M.; Kubicek, C.; Saddler, J.; Xu, F. Bioenergy Research. Advances and Applications; Elsevier: Amsterdam, The Netherlands, 2014; ISBN 978-0-444-59561-4. 
19. Mehmood, M.A.; Ibrahim, M.; Rashid, U.; Nawaz, M.; Ali, S.; Hussain, A.; Gull, M. Biomass production for bioenergy using marginal lands. Sustain. Prod. Consum. 2017, 9, 3-21. [CrossRef]

20. Kingwell, R.; Abadi, A. Cereal straw for bioenergy production in an Australian region affected by climate change. Biomass Bioenergy 2014, 61, 58-65. [CrossRef]

21. Portugal-Pereira, J.; Soria, R.; Rathmann, R.; Schaeffer, R.; Szklo, A. Agricultural and agro-industrial residues-to-energy: Techno-economic and environmental assessment in Brazil. Biomass Bioenergy 2015, 81, 521-533. [CrossRef]

22. Raslavicius, L.; Kucinskas, V.; Jasinskas, A. The prospects of energy forestry and agro-residues in the Lithuania's domestic energy supply. Renew. Sustain. Energy Rev. 2013, 22, 419-431. [CrossRef]

23. Manos, B.; Bartocci, P.; Partalidou, M.; Fantozzi, F. Review of public-private partnerships in agro-energy districts in Southern Europe: The cases of Greece and Italy. Renew. Sustain. Energy Rev. 2014, 39, 667-678. [CrossRef]

24. Fantozzi, F.; Bartocci, P.; D’Alessandro, B.; Arampatzis, S.; Manos, B. Public-private partnerships value in bioenergy projects: Economic feasibility analysis based on two case studies. Biomass Bioenergy 2014, 66, 387-397. [CrossRef]

25. Manos, B.; Partalidou, M.; Fantozzi, F.; Arampatzis, S.; Papadopoulou, O. Agro-energy districts contributing to environmental and social sustainability in rural areas: Evaluation of a local public-private partnerships scheme in Greece. Renew. Sustain. Energy Rev. 2014, 29, 85-95. [CrossRef]

26. Venanzi, S.; Pezolla, D.; Cecchini, L.; Pauselli, M.; Ricci, A.; Sordi, A.; Torquati, B.; Gigliotti, G. Use of agricultural by-products in the development of an agro-energy chain: A case study from the Umbria region. Sci. Total Environ. 2018, 627, 494-505. [CrossRef] [PubMed]

27. CNE. Valor de la Energía más Bajo en la Historia de las Licitaciones. Available online: https: / / www.cne.cl/prensa/prensa-2017/11-noviembre-2017/valor-de-la-energia-mas-bajo-en-la-historiade-las-licitaciones-en-chile/ (accessed on 12 March 2018).

28. The Central Interconnected System Is the Electric Network That Integrates from Center to South of Chile. It Serves $92 \%$ of National Population. Available online: https:/ / sic.coordinador.cl/sobre-sic/ (accessed on 12 March 2018).

29. From November 2017, the CIS Joined with North Electric Network, Creating the National Electric System, That Serves to $96 \%$ of National Population. Available online: https:/ / www.coordinador.cl/sistema-electriconacional/ (accessed on 12 March 2018).

30. CORMA. Biomasa Forestal: Una Energía Renovable con Proyección en Chile, 21 de Julio de 2014. Available online: http:/ / www.corma.cl/corma-al-dia/biobio/biomasa-forestal-una-energia-renovable-conproyeccion-en-chile (accessed on 12 March 2018).

31. LIGNUM. Biomasa en Chile: El Debate que Viene, 3 de Agosto de 2015. Available online: http:/ / www. lignum.cl/reportajes/biomasa-en-chile-el-debate-que-viene/\# (accessed on 12 March 2018).

32. Chile Energías. Arauco Logró Ventas de Energía por US\$ 92 Millones en 2015, 22 de Enero de 2016. Available online: https: / / www.chileenergias.cl/2016/01/22/arauco-logro-ventas-de-energia-por-us92millones-en-2015/ (accessed on 12 March 2018).

33. GPM AG. Bioenergías Forestales S.A. Se Integra Como Asociado de GMP AG, Octubre de 2015. Available online: https://gpm-ag.cl/bioenergias-forestales-s-a-se-integra-como-asociado-de-gpm-ag/ (accessed on 12 March 2018).

34. Pacheco, A. Energía Verde S.A. Bioenergía: Experiencia y Futuro. Seminario Bioenergía, 24 de Noviembre de 2016: Talca, Chile. Available online: https:/ / www.odepa.gob.cl/odepaweb/publicaciones/ SemBiocombustibles/17_Biocombustibles-Energia_Verde.pdf (accessed on 12 March 2018).

35. Pinto, J.; Órdenes, M. Chile, Una Economía Regional en el Siglo XX. La Araucanía, 1900-1960; Ediciones de la Universidad de La Frontera: Temuco, Chile, 2012; ISBN 9789562362214.

36. Almonacid, F. La Agricultura Chilena Discriminada (1910-1960). Una Mirada de las Políticas Estatales y el Desarrollo Sectorial Desde el sur; CSIC: Madrid, España, 2009; ISBN 9788400088699.

37. Almonacid, F. El problema de la propiedad de la tierra en el sur de Chile (1850-1930). Historia 2009, 42, 5-56. [CrossRef]

38. Ministerio de Desarrollo Social. Informe de Desarrollo Social 2015; Ministerio de Desarrollo Social: Santiago de Chile, Chile, 2015; Available online: http://www.ministeriodesarrollosocial.gob.cl/pdf/ upload/IDS2.pdf (accessed on 23 March 2018). 
39. Apey, A.; Gumucio, A.; Tapia, B. Variaciones en el uso del suelo agropecuario y forestal chileno: Comparación de los censos agropecuarios de 1976, 1997 y 2007. Agricultura en Cifras 2009, 1, 1-10. Available online: https:/ / www.odepa.gob.cl/odepaweb/publicaciones / Agrocifras / Agricultura_en_cifras_001.pdf (accessed on 23 March 2018).

40. INE. Compendio Estadístico. Región de La Araucanía 2015; INE Araucanía: Temuco, Chile, 2015; Available online: http://www.inearaucania.cl/archivos/files/pdf/SistemaEstadisticoRegional/ Compendio\%20Estad\%C3\%ADstico\%20Regional\%202015\%20-\%20La\%20Araucan\%C3\%ADa.pdf (accessed on 23 March 2018).

41. Paneque, M.; Román-Figueroa, C.; Vázquez-Panizza, R.; Arriaza, J.M.; Morales, D.; Zulantay, M. Bioenergía en Chile; FAO-Universidad de Chile: Santiago de Chile, Chile, 2011; Available online: http:/ /www.fao.org/ 3/a-as183s.pdf (accessed on 23 March 2018).

42. Durán, J. Casen 2013. forme de Resultados Regionales Sobre la Medición de la Pobreza Multidimensional (2009-2013). Ministerio de Desarrollo Social: Santiago de Chile, Chile, 2016. Available online: http:/ / observatorio.ministeriodesarrollosocial.gob.cl/documentos/RESULTADOS_REGIONALES_SOBRE_ LA_MEDICION_POBREZA_MULTIDIMENSIONAL_2009-2013.pdf (accessed on 23 March 2018).

43. Estimaciones de Tasas de Pobreza por Ingresos por Comunas. 2013. Available online: http:/ / observatorio.ministeriodesarrollosocial.gob.cl/documentos / Estimacion_tasa_de_pobreza_ comunal_2013_(nueva_metodologia)-1.xlsx.zip (accessed on 23 March 2018).

44. Torres-Salinas, R.; Azócar, G.; Carrasco, N.; Zambrano-Bigiarini, M.; Costa, T.; Bolin, B. Desarrollo forestal, escasez hídrica y la protesta social mapuche por la justicia ambiental en Chile. Ambient. Soc. 2016, 19, $122-146$. Available online: http:/ / www.scielo.br/pdf/asoc/v19n1/pt_1809-4422-asoc-19-01-00121.pdf (accessed on 23 March 2018).

45. Andrade, F. Actualización y Relación de Plantaciones Forestales y Déficit Hídrico en Comunas de la Región de La Araucanía, Chile. Temuco, Chile, 2016. Available online: http:/ /www.mapuexpress.org/wp-content/ uploads/2016/03/D\%C3\%A9ficit-h\%C3\%ADdrico-y-plantaciones-forestales-en-la-Regi\%C3\%B3n-deLa-Araucan\%C3\%ADa.pdf (accessed on 23 March 2018).

46. Navarro, L.; Andrea, M. Modelo de Generación de Energía a Partir de Biomasa Forestal. Memoria de pregrado, Universidad de Chile. 2015. Available online: http:/ / repositorio.uchile.cl/handle/2250/134250 (accessed on 27 November 2018).

47. Análisis de la situación actual y futura del consumo de biomasa forestal para generación en Chile. 2014. Available online: http:/ / cybertesis.uach.cl/tesis/uach/2014/fifg984a/doc/fifg984a.pdf (accessed on 27 November 2018).

48. Altamirano, A.; Schlegel, B.; Thiers, O.; Miranda, A.; Pilquinao, B.; Orrego, R.; Rocha, C. Biomass stock and potential energy for the dendroenergy development based of native forests of South-Central Chile. Bosque 2015, 36, 223-237. [CrossRef]

49. Román-Figueroa, C.; Montenegro, N.; Paneque, M. Bioenergy potential from crop residue biomass in Araucanía Region of Chile. Renew. Energy 2017, 102, 170-177. [CrossRef]

50. Gerding, V.; An der Fuhren, F.; Holmqvist, C.; Almonacid, B.; Ceballos, R. Evaluación del Mercado de Biomasa y su Potencial: Estimación de Superficie Disponible para el Establecimiento de Plantaciones Dendroenergéticas; Informe Final; Universidad Austral de Chile: Valdivia, Chile, 2013.

51. Data of Censo de Población y Vivienda 2017. Available online: http://www.censo2017.cl/ (accessed on 11 April 2018).

52. Information about Comasa Company. Available online: http://www.comasageneracion.cl/ (accessed on 11 April 2018).

53. Diario El Sur. Papelera Concepción Producirá su Energía, 20 de Diciembre de 2005. Available online: http: / / www.lignum.cl/2005/12/20/papelera-concepcion-producira-su-energia/\# (accessed on 11 April 2018).

54. Francisco Bebin Campos. Cogeneración de Energía de Forestal y Papelera Concepción S.A. 25 de Noviembre de 2005. Available online: http:/ / seia.sea.gob.cl/expediente/ficha/fichaPrincipal.php?modo=normal\&id_ expediente $=1132975$ (accessed on 11 April 2018).

55. González, F. Comasa Generación S.A. Sed de biomasa. Lignum 2012, 133, 39-42.

56. Madariaga, F. Chief Procurement Officer and Administrator Comasa. Personal Communication, 2018. 
57. Comasa, S.A. Proyecto Generación Energía Renovable Lautaro, 11 de Marzo de 2010. Available online: http: / / seia.sea.gob.cl/expediente/ficha / fichaPrincipal.php? modo=normal\&id_expediente=4172357 (accessed on 11 April 2018).

58. Mora Sanhueza, C. Biomass Supplier Comasa and Entrepreneur of Agricultural Services. Personal Communication, 2018.

59. Comasa, S.A. Aprovechamiento Energético de Paja de Cereales en Unidad N ${ }^{\circ} 2$ Central de Energía Renovable, 23 de Octubre de 2012. Available online: http:/ / seia.sea.gob.cl/expediente/ficha / fichaPrincipal.php?modo= normal\&id_expediente=7462844 (accessed on 11 April 2018).

60. Madariaga, F. Experiencia Comasa en el uso de Biomasa para la Generación de Energía. Seminario Biomasa Forestal. Contribución y valor en la Generación de Energías Renovables, Concepción, Chile, Octubre 2017. Available online: https:/ /www.infor.cl/images/pdf/Seminario_Biomasa/6_Presentacion_COMASA.pdf (accessed on 12 April 2018).

61. Colbún, S.A. Memoria Anual 2013; Colbún: Santiago de Chile, Chile, 2014; p. 8. Available online: http: / / memoria.colbun.cl/2013/pdfs/Memoria_Colbun_2013.pdf (accessed on 12 April 2018).

62. Madariaga, F. PDP Comasa Bioenergía Lautaro; Comasa: Lautaro, Chile, 2017.

63. Neira, K. Administrator Agent Operator Department, SOFO. Personal Communication, 2018.

64. González, F. Costos Marginales de la Electricidad Llegan a su Nivel más bajo Desde 2006, 26 de Diciembre de 2017. Diario La Tercera. Available online: http:/ / www2.latercera.com/noticia/costos-marginales-laelectricidad-llegan-nivel-mas-desde-2006/ (accessed on 12 April 2018).

65. Rakun SPA. Aprovechamiento Energético Biomasa Agrícola, Región de La Araucanía, 19 de Noviembre de 2014. Available online: http:/ / seia.sea.gob.cl/expediente/ficha/fichaPrincipal.php?modo=ficha\&id_ expediente $=2129975052$ (accessed on 4 June 2018).

66. INDH. Mapa de Los Conflictos Socioambientales en Chile 2015; INDH: Santiago de Chile, Chile, 2016; ISBN 9789569025853.

67. Resolución Exenta No 166, Cristián Lineros, Director Regional Servicio Evaluación Ambiental Región de La Araucanía, 2 de Mayo de 2018, Temuco. Available online: http:/ /infofirma.sea.gob.cl/DocumentosSEA/ MostrarDocumento?docId=5c/7e/5db6ea5a13dbe5323b6614b7dde6ecc890e4 (accessed on 22 August 2018).

68. Energías Victoria, S.A. Planta de Generación Eléctrica a Partir de Biomasa de 20 MW Victoria, 21 de Junio de 2016. Available online: http:/ / seia.sea.gob.cl/expediente/ficha/fichaPrincipal.php? modo=ficha\&id_ expediente $=2131510791$ (accessed on 4 June 2018).

69. Reporte Sostenible. Futura Planta de Biomasa de Victoria Podría Reducir la Contaminación de la Zona en un 80\%, 5 de Octubre de 2017. Available online: http:/ / www.reportesostenible.cl/Futura-planta-de-biomasade-Victoria-podria-reducir-la-contaminacion-de-la-zona-en-un-80 (accessed on 4 June 2018).

70. Pulso Diario. Alcalde de Lautaro Plantea Cuestionamientos por Inauguración de Termoeléctrica Comasa, 14 de Marzo de 2013. Available online: http:/ / www.pulsodiario.cl/archives/13150 (accessed on 12 April 2018).

71. Radio Universal. Alcalde de Lautaro Sostiene que Intendente Aparece Como Vocero de la Termoeléctrica, 20 de Marzo de 2013. Available online: http://www.radiouniversal.cl/2015/alcalde-de-lautarosostiene-que-intendente-aparece-como-vocero-de-termoelectrica-y-se-salta-institucionalidad/ (accessed on 12 April 2018).

72. Martínez, C. Incendio Afecta Instalaciones de Planta Termoeléctrica Comasa en las Afueras de Lautaro, 13 de Febrero de 2014. Radio Biobio. Available online: https:/ / www.biobiochile.cl/noticias/2014/02/13/ incendio-afecta-termoelectrica-comasa-en-las-afueras-de-lautaro.shtml (accessed on 12 April 2018).

73. The FPC Company, Owner of Comasa, Tried to Establish One More Plant of Agricultural Biomass in Mulchén, Bío-Bío Region, 2015, But Your Proposal Was Denied by Environmental Assessment. Energía FPC S.A. Bioenergy Central Las Maicas, 22 June 2015. Available online: http:/ / seia.sea.gob.cl/expediente/ficha/ fichaPrincipal.php?modo=ficha\&id_expediente=2130565030 (accessed on 12 April 2018).

74. Biodiversidadla.org. Chile: Comunidades Mapuche de Freire Iniciarán Acciones Judiciales por Futura Termoeléctrica de la Empresa Rakun SPA, 27 Enero de 2016. Available online: http:/ / www.biodiversidadla.org/Noticias/Chile_Comunidades_mapuche_de_Freire_iniciaran_acciones_ judiciales_por_futura_termoelectrica_de_la_empresa_Rakun_SpA (accessed on 4 June 2018). 
75. Fundación Terram. Comunidad Mapuche de Freire Presenta Recurso de Protección Contra Proyecto Aprobado de Termoeléctrica, 11 de Mayo de 2016. Available online: http://www.terram.cl/2016/ 05/comunidad-mapuche-de-freire-presenta-recurso-de-proteccion-contra-proyecto-aprobado-determoelectrica/ (accessed on 4 June 2018).

76. Red Defensa Territorios, 12 de Enero de 2016. Available online: http://kaosenlared.net/chile-mapuchesigue-el-saqueo-por-unanimidad-gobierno-regional-araucania-aprobo-termoelectrica-en-comuna-defreire/ (accessed on 4 June 2018).

77. Red Defensa Territorios. Proyectos de Energía Aprobados en La Araucanía, 27 de Diciembre de 2015. Available online: http://www.mapuexpress.org/?p=6467\&fbclid=IwAR1mvfrDle3uPis1FEi7exFrw6DF97Vlpxq6yLYyV4hx6ysj1_QnuTsxgg (accessed on 22 August 2018).

78. Somos. Alcalde Javier Jaramillo hace Llamado a Activar Proyectos Aprobados en Energía Renovable en Malleco, 9 de Julio de 2018. Available online: http:/ / somos9.cl/2018/07/09/alcalde-javier-jaramillo-hacellamado-a-activar-proyectos-aprobados-en-energia-renovable-en-malleco/ (accessed on 22 August 2018).

(C) 2018 by the author. Licensee MDPI, Basel, Switzerland. This article is an open access article distributed under the terms and conditions of the Creative Commons Attribution (CC BY) license (http:// creativecommons.org/licenses/by/4.0/). 